\title{
Effect of physicochemical parameters on the polygalacturonase of an Aspergillus sojae mutant using wheat bran, an agro-industrial waste, via solid-state fermentation
}

\author{
Hande Demir ${ }^{a}$ and Canan Tarib*
}

\begin{abstract}
BACKGROUND: Polygalacturonases (PGs) are valuable enzymes of the food industry; therefore it is of great importance to discover new and GRAS PG-producing microbial strains. In this study, PG enzyme produced from a high PG activity producer mutant Aspergillus sojae using wheat bran at the flask scale under pre-optimized conditions of solid-state fermentation (SSF) was biochemically characterized.

RESULTS: The crude PG enzyme showed optimum activity in the pH range 4.0-5.0 and was stable in the pH range 3.0-7.0. The optimum temperature for the PG was $40^{\circ} \mathrm{C}$ and it retained $99 \%$ of its activity at $50^{\circ} \mathrm{C}$. The mutant $A$. sojae PG could preserve more than $50 \%$ of its stability between 25 and $50^{\circ} \mathrm{C}$, both for 30 and $60 \mathrm{~min}$, and was found to be stable in the presence of most of the tested compounds and metal ions. The inactivation energy $\left(E_{\mathrm{d}}\right)$ was determined as $125.3 \mathrm{~kJ} \mathrm{~mol}^{-1}$. The enthalpy $\left(\Delta H^{*}\right)$, free energy $\left(\Delta G^{*}\right)$ and entropy $\left(\Delta S^{*}\right)$ of inactivation were found to be stable with increasing temperature.
\end{abstract}

CONCLUSION: The mutant $A$. sojae PG could be suitable for the clarification (depectinization) of orange and grape juices and wine.

() 2015 Society of Chemical Industry

Keywords: Exo-polygalacturonase; Aspergillus sojae; biochemical characterization; fungal pectinase

\section{INTRODUCTION}

Polygalacturonases (PGs), important and widely used enzymes of the food industry, belong to the group of pectic enzymes involved in the degradation of pectic substances. ${ }^{1}$ They are classified under depolymerases. PGs catalyze the hydrolysis of $\alpha-1,4$-glycosidic linkages in pectic acid with the introduction of water across the oxygen bridge. ${ }^{2}$ PGs have subgroups depending on the pattern of action (random or terminal).

Endo-PGs (EC 3.2.1.15) are known as poly(1,4- $\alpha$-D-galacturonide) glycanohydrolases, catalyzing the random hydrolysis of $\alpha-1,4$-glycosidic linkages in pectic acid. This reaction produces oligogalacturonates. They are widely distributed among fungi, bacteria, many types of yeast, higher plants and some plant parasitic nematodes. $^{2-4}$ Exo-PGs (EC 3.2.1.67) are known as poly $(1,4-\alpha$-D-galacturonide)galacturonohydrolases, catalyzing the hydrolysis of $\alpha-1,4$-glycosidic linkages in pectic acid in a sequential fashion. In contrast to endo-PGs, exo-PGs occur less frequently and can be distinguished as two types, namely fungal exo-PGs that liberate monogalacturonic acid as the main end product and bacterial exo-PGs that liberate digalacturonic acid as the main end product.

Solid-state fermentation (SSF) is an environmentally friendly technique in which agro-industrial residues are generally considered as the best substrates, especially for the production of enzymes. In the current study, a PG was produced by SSF that enabled adding value to wheat bran, a widely produced residue of the food industry.

The biochemical properties of microbial PGs may vary according to the type of microbial source, fermentation method and production conditions. Moreover, the biochemical properties of PGs should be appropriate for their biotechnological application area. Some biochemical and physicochemical properties of exo-PGs produced by various microorganisms are shown in Table 1.

Table 1 shows that the optimum temperatures of the enzymatic activity of PGs are mostly between 40 and $60^{\circ} \mathrm{C}$. Additionally, most of the PGs show optimum activity at acidic to neutral $\mathrm{pH}$ values at these temperatures. The stability of the produced PGs changes between the temperatures of 40 to $70^{\circ} \mathrm{C}$ for approximately $30 \mathrm{~min}$ to $1 \mathrm{~h}$. However, interestingly, Kapoor et al. ${ }^{11}$ managed to produce a thermo/alkali-stable PG with an extreme optimum $\mathrm{pH}$ of 10.0. This PG also showed marked thermostability by retaining $100 \%$ of

\footnotetext{
* Correspondence to: Canan Tari, Department of Food Engineering, Izmir Institute of Technology, Gulbahce Campus, TR-35430 Urla, Izmir, Turkey E-mail: canantari@iyte.edu.tr

a Department of Food Engineering, Osmaniye Korkut Ata University, TR-80000, Osmaniye, Turkey

b Department of Food Engineering, Izmir Institute of Technology, Gulbahce Campus, TR-35430, Urla, Izmir, Turkey
} 
in

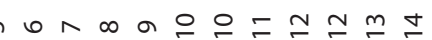

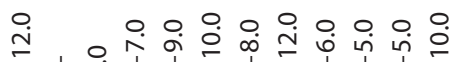

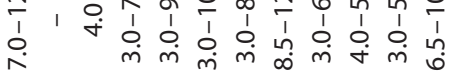

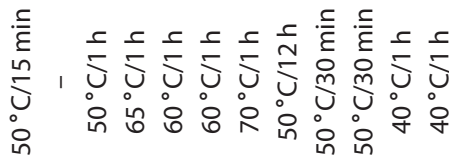

工ٓ

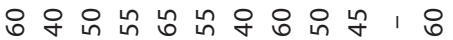

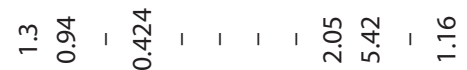

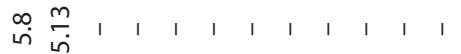

กำ

\section{is}

its enzymatic activity at $50^{\circ} \mathrm{C}$ for more than $12 \mathrm{~h}$. This was a partially purified PG produced from a Bacillus $\mathrm{sp}$. isolated from the outer covering of seeds of Celastrus paniculatus. ${ }^{11}$ Table 1 indicates that most of the produced PGs were stable over a wide $\mathrm{pH}$ range. The PG produced by SSF from Moniliella sp. on a mixture of orange bagasse, sugar cane bagasse and wheat bran has the broadest $\mathrm{pH}$ stability, since it preserved $70-100 \%$ of its initial enzymatic activity between $\mathrm{pH} 3.0$ and 10.0. ${ }^{10}$ Acuna-Arguelles et al. ${ }^{12}$ compared the properties of exo-pectinases produced by SSF and submerged fermentation ( $\mathrm{SmF}$ ) techniques from Aspergillus niger $\mathrm{CH} 4$. They observed that the $K_{\mathrm{m}}$ values of the PGs obtained from the same fungal strain were different depending on the type of fermentation. Table 1 also shows that the majority of the PGs have a molecular weight in the range $30-70 \mathrm{kDa}$.

This study involved the biochemical characterization of PG enzyme produced from mutant Aspergillus sojae using wheat bran at the flask scale under pre-optimized conditions. Since this mutant was reported as a high PG enzyme producer by Demir and Tari, ${ }^{15}$ it was thought to be important to state the biochemical properties to enlighten its potential and effective use. The purpose of the biochemical characterization was to understand the activity or stability behavior of the produced enzyme under different conditions as well as its thermal inactivation kinetics and thermodynamic parameters of inactivation in order to evaluate its potential applications in the area of biotechnology and food engineering.

\section{MATERIALS AND METHODS Microorganism and inoculum preparation}

Aspergillus sojae ATCC 20235 (wild type) was purchased in lyophilized form from LGC Promochem, Inc., (Teddington, Great Britain) an international distributor of ATCC (American Type Culture Collection) in Europe. This wild-type culture was randomly mutated using ultraviolet light exposure according to the modified method of Nicolás-Santiago et al. ${ }^{16}$ by Jacobs University $\mathrm{GmbH}$, Bremen and used as the mutant in this study. After the propagation step on YME (yeast malt extract) agar plates, the spore suspensions used as inoculum were obtained on molasses agar slants given by Göğüş et al. ${ }^{17}$ The inoculum preparation procedure for SSF was done according to Demir et al. ${ }^{18}$

\section{Enzyme production by SSF}

A $10 \mathrm{~g}$ portion of wheat bran (Hazal Flour and Feed Manufacturing Company, Turgutlu, Turkey) was placed in a $250 \mathrm{~mL}$ Erlenmeyer flask. The physicochemical composition of the wheat bran used in this study was characterized and summarized by Demir and Tari. ${ }^{15}$ Half of the appropriate amount of distilled water calculated to maintain the desired initial moisture content was added to the medium before sterilization. The other half of the distilled water was sterilized and used for the inoculation including the sufficient inoculum concentration. The content of the flask was mixed well until the homogeneous spread of the inoculum on the solid substrate was obtained and then placed in a static incubator. Fermentation conditions were optimized in a previous study $^{15}$ as $10^{7}$ spores $\mathrm{g}^{-1}$ substrate inoculum size, 4 days of $\mathrm{SSF}$, incubation temperature of $37^{\circ} \mathrm{C}, 620 \mathrm{~g} \mathrm{~kg}^{-1}$ initial moisture content, neutral $\mathrm{pH}, 150-250 \mu \mathrm{m}$ particle size of wheat bran, 3 times day ${ }^{-1}$ agitation frequency and spore inoculum type.

\section{Enzyme extraction}

After a gentle dry homogenization, $10 \mathrm{~g}$ of the fermented sample was placed in a $250 \mathrm{~mL}$ Erlenmeyer flask and added with Tween 
$80\left(0.2 \mathrm{~g} \mathrm{~L}^{-1}\right)$ solution in order to extract the PG enzyme into the aqueous phase in the ratio of 1:10 (sample amount/Tween 80 solution) in two replicates. The content was dispersed with a glass baguette until a homogeneous mixture was obtained and then shaken at $150 \mathrm{rpm}$ and $25^{\circ} \mathrm{C}$ for $30 \mathrm{~min}$. Afterwards, the $\mathrm{pH}$ was measured with a $\mathrm{pH}$ meter and the content was filtered through cheesecloth and centrifuged at $5000 \times g$ for $15 \mathrm{~min}$ at $4{ }^{\circ} \mathrm{C}$. The supernatant was separated and used for enzyme assays immediately.

\section{Determination of enzyme activity}

PG activity was assayed according to the modified procedure of Panda et al. ${ }^{19}$ using $2.4 \mathrm{~g} \mathrm{~L}^{-1}$ polygalacturonic acid as substrate. One unit of enzyme activity was defined as the amount of enzyme that catalyzes the release of $1 \mu \mathrm{mol}$ galacturonic acid per unit volume of culture filtrate per unit time under standard assay conditions ( $\mathrm{pH} 4.8$ and $40^{\circ} \mathrm{C}$ ). Galacturonic acid (Sigma, St Louis, MO, USA) was used as standard for the calibration curve of PG activity.

\section{Effect of pH on activity and stability of PG}

The $\mathrm{pH}$ values investigated were 3.0, 4.0, 5.0, 6.0, 7.0, 8.0, 9.0, 10.0, 11.0 and 12.0 . In these analyses the $\mathrm{pH}$ was adjusted using the following buffer systems: acetate $(\mathrm{pH} 3.0,4.0,5.0)$, phosphate $(\mathrm{pH} 6.0$, 7.0, 8.0), Tris- $\mathrm{HCl}(\mathrm{pH} 9.0,10.0)$ and $\mathrm{Na}_{2} \mathrm{HPO}_{4}-\mathrm{NaOH}(\mathrm{pH} 11.0,12.0)$. The concentration of each buffer was $0.1 \mathrm{~mol} \mathrm{~L}^{-1}$. The optimum $\mathrm{pH}$ of PG was determined by the standard PG activity assay (see above) with polygalacturonic acid $\left(2.4 \mathrm{~g} \mathrm{~L}^{-1}\right)$ as substrate dissolved in the buffer systems mentioned. To study the stability as a function of $\mathrm{pH}$, the crude enzyme was mixed (1:1) with the buffer solutions mentioned above and aliquots of the mixture were taken to measure the residual PG activity (\%) under standard assay conditions after incubation at $30^{\circ} \mathrm{C}$ for $2 \mathrm{~h}$. Experiments were conducted in three parallels.

\section{Effect of temperature on activity and stability of PG}

The optimum temperature of the PG was determined by incubating the reaction mixture $(\mathrm{pH} 4.8)$ for $20 \mathrm{~min}$ at different temperatures ranging from 25 to $80^{\circ} \mathrm{C}\left(25,30,40,50,60,70\right.$ and $\left.80^{\circ} \mathrm{C}\right)$ and measuring the activity by the standard PG activity assay. Before the addition of enzymes, the substrate $\left(2.4 \mathrm{~g} \mathrm{~L}^{-1}\right.$ polygalacturonic acid) was pre-incubated at the respective temperature for $10 \mathrm{~min}$. The thermostability of the crude PG was investigated by measuring the residual activity after incubating the enzyme at various temperatures ranging from 25 to $80^{\circ} \mathrm{C}(25,30,40,50,60,70$ and $80^{\circ} \mathrm{C}$ ) for 30 and $60 \mathrm{~min}$. The incubation medium used was $0.1 \mathrm{~mol} \mathrm{~L}^{-1}(\mathrm{pH} 4.8)$ sodium acetate buffer system. Experiments were conducted in three parallels.

\section{Effect of metal ions and various compounds on PG stability}

The effect of various metal ions and chemical compounds was investigated by incubating the PG enzyme in the presence of the reagents given in Table 2 in the volumetric ratio of 1:1 at $30^{\circ} \mathrm{C}$ for $1 \mathrm{~h}$. At the end of this incubation period, appropriate aliquots were taken and the standard PG activity assay was conducted immediately to measure their residual PG activities. The control of this set of experiments was the untreated PG enzyme and its PG activity was taken as $100 \%$. The concentrations of acetic acid, citric acid, sucrose, glucose, fructose, gallic acid, malic acid, ascorbic acid and ethanol were chosen according to the
Table 2. Effect of various metal ions and compounds on stability of PG activity

Metal ion/

Residual

chemical compound

Concentration

PG activity (\%)

Control

Acetic acid

Citric acid

Sucrose

Glucose

Fructose

Gallic acid

Malic acid

Tartaric acid

Ascorbic acid

Ammonium sulfate

$\mathrm{CaCl}_{2}$

$\mathrm{MgCl}_{2}$

$\mathrm{CuSO}_{4}$

$\mathrm{KCl}$

$\mathrm{FeCl}_{3}$

$\mathrm{MnCl}_{2}$

$\mathrm{NaCl}$

EDTA

Ethanol
100.00

118.99

116.86

117.16

118.66

82.33

135.03

129.48

122.48

132.83

141.55

93.08

117.02

107.48

108.81

76.28

126.51

107.82

124.83

113.02

chemical characterization of orange juice and wine (cv. Kozan, Turkey) obtained by high-pressure liquid chromatography (HPLC) analyses. ${ }^{20}$ The concentration of tartaric acid was based on the determination of organic acids in white grape juice by liquid chromatography/tandem mass spectrometry (LC/MS/MS) analysis. ${ }^{21}$ The concentration of ammonium sulfate was determined according to the maximum limit of ammonium sulfate that is allowed in grape cider as stated in the wine communication under Turkish Food Codex Regulations (notification no. 2008/67). ${ }^{22}$

\section{Kinetics of thermal inactivation and estimation of inactivation energy}

The enzyme samples were incubated at temperatures of 30,40, 50 and $60^{\circ} \mathrm{C}$ for 30 and $60 \mathrm{~min}$ for the thermal inactivation kinetic studies. Aliquots were withdrawn and cooled in an ice bath prior to the standard PG activity assay. The residual activity was expressed as a percentage of the initial activity. Inactivation rate constants $\left(k_{d}\right)$ were calculated from the slopes of the curves in the semi-logarithmic plot of residual activity vs time and apparent half-lives $\left(t_{1 / 2}\right.$, time where residual activity reaches $\left.50 \%\right)$ were estimated as

$$
t_{1 / 2}=(\ln 2) / k_{\mathrm{d}}
$$

An Arrhenius plot was used to analyze the variation in $k_{d}$ according to the temperature. ${ }^{23}$ The inactivation energy $\left(E_{d}\right)$ was calculated from the Arrhenius equation

$$
k_{\mathrm{d}}=k_{0} \exp (-E / R T)
$$

or

$$
\ln k_{\mathrm{d}}=\left(\ln k_{0}\right)[-(E / R)(1 / T)]
$$

The values of $E_{\mathrm{d}}$ and $k_{0}$ were estimated respectively from the slope and intercept of the plot of In $k_{d} v s 1 / T$ obtained from Eqn (3) $\left(R=8.3145 \mathrm{~J} \mathrm{~mol}^{-1} \mathrm{~K}^{-1}\right)$. 


\section{Estimation of thermodynamic parameters during}

\section{inactivation of PG}

Equation (4) was used to calculate the enthalpy of inactivation $\left(\Delta H^{*}\right)$ for each temperature:

$$
\Delta H^{*}=E_{\mathrm{d}}-R T
$$

Equation (5) was used for calculation of the Gibbs free energy $\left(\Delta G^{*}\right)$ of inactivation from the first-order constant of the inactivation process at different temperatures:

$$
\Delta G^{*}=-R T \ln \left(k_{\mathrm{d}} h / \kappa T\right)
$$

where $h=6.6262 \times 10^{-34} \mathrm{~J} \mathrm{~s}$ is the Planck constant and $\kappa=1.3806 \times 10^{-23} \mathrm{~J} \mathrm{~K}^{-1}$ is the Boltzmann constant.

From Eqns (4) and (5) the entropy of inactivation $\left(\Delta S^{*}\right)$ was calculated as ${ }^{24}$

$$
\Delta S^{*}=\left(\Delta H^{*}-\Delta G^{*}\right) / T
$$

\section{Sodium dodecyl sulfate polyacrylamide gel electrophoresis} (SDS-PAGE) analysis of PG enzymes

The crude PG enzyme samples were analyzed by the SDS-PAGE method $^{25}$ using $120 \mathrm{~g} \mathrm{~L}^{-1}$ acrylamide separating gel ( $\left.\mathrm{pH} 8.5\right)$ and $40 \mathrm{~g} \mathrm{~L}^{-1}$ acrylamide stacking gel ( $\left.\mathrm{pH} 6.5\right)$.

The total protein contents of the samples were measured by the Bradford ${ }^{26}$ method and obtained as 0.28, 0.37, 0.42, 0.79 and $8.5 \mathrm{mg} \mathrm{mL}^{-1}$ for the submerged (SmF), flask, drum bioreactor, tray bioreactor (SSF) PG produced by the mutant $A$. sojae and commercial pectinase (Pectinase from A. niger, Sigma P2736, $50 \mathrm{~mL}$ ) enzymes respectively. The submerged fermentation-type PG enzyme was kindly supplied by Nihan Göğüş and was produced under optimized conditions using orange peel as the substrate in a serial-type $1 \mathrm{~L}$-scale bioreactor from the same mutant of $A$. sojae. ${ }^{27}$ The flask PG was produced under optimum conditions in a previous study. ${ }^{15}$ The drum bioreactor sample was taken from the 55 th hour of the SSF process using wheat bran. ${ }^{28}$ The enzyme sample from tray-type fermentation was obtained at $70 \%$ relative humidity using wheat bran. ${ }^{29}$ The commercial pectinase was diluted to $1 / 100$ with sodium acetate buffer $(\mathrm{pH} 4.8)$; however, the other samples were not diluted since they had low protein concentrations close to each other. Staining of the gel was done by the silver staining technique. ${ }^{30}$ The gel was visualized by BioRad VersaDoc Imaging System (BioRad, Hercules, CA, USA) and processed by Quantity One software (BioRad).

\section{RESULTS AND DISCUSSION}

\section{Effect of pH on activity and stability of PG}

The results of the effect of $\mathrm{pH}$ on the PG activity are presented in Fig. 1. The $\mathrm{pH}$ values of the reaction mixture were adjusted by various buffers ranging from $\mathrm{pH} 3.0$ to 12.0 as detailed above. As can be seen in Fig. 1, the produced PG enzyme showed significant activity mainly in the acidic region ( $\mathrm{pH} 4.0-5.0)$. It is thought that with the change in $\mathrm{pH}$ the ionization of essential active site amino acid residues was affected, which are involved in substrate binding and catalysis, i.e. breakdown of the substrate into products. ${ }^{24}$ The enzyme was found to be a typical acidic pectinase displaying its activity on polygalacturonic acid in the acidic region of $\mathrm{pH} 4.0-5.0$. This result confirmed the use of the reaction mixture at $\mathrm{pH} 4.8$ in all enzymatic activity assays of the PG conducted in this study. Some biochemical properties of fungal PGs were reviewed by Niture $^{1}$ recently. It was observed that most of the fungal PG

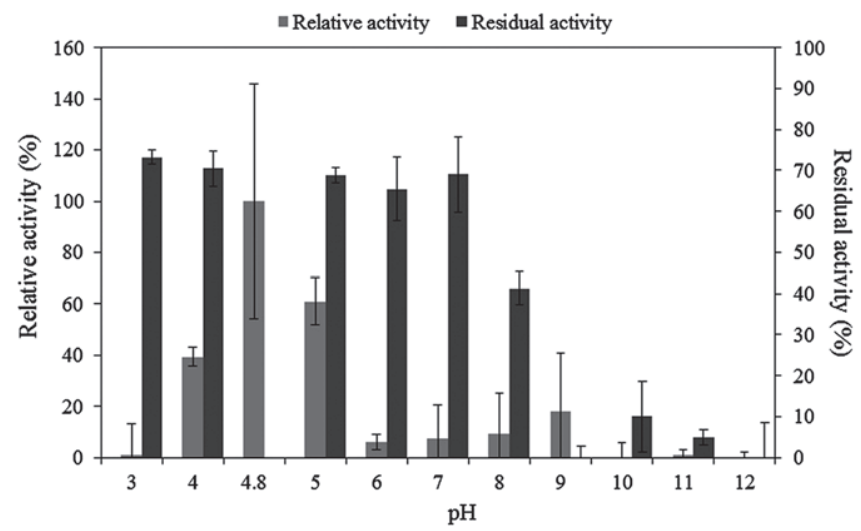

Figure 1. Effect of $\mathrm{pH}$ on activity and stability of mutant Aspergillus sojae PG.

enzymes stated in the literature had maximum activity in the acidic $\mathrm{pH}$ range $2.0-5.5$. Dinu et al. ${ }^{6}$ reported a PG enzyme having an optimum activity at $\mathrm{pH} 4.6$ against sodium polygalacturonate. This purified (by chromatographic methods) PG obtained from an $A$. niger strain lost its activity rapidly beyond $\mathrm{pH} 5.0$, similarly to the PG produced in the current study. Another PG produced by Thermoascus aurantiacus was also reported to lose most of its activity outside the range of $\mathrm{pH} 3.5-5.5{ }^{9}$ The PG enzyme produced in the current study is thought to have potential in the enzymatic clarification (depectinization) of fruit juices, which mostly have acidic $\mathrm{pH}$ values.

The stability of the mutant $A$. sojae PG was investigated in the $\mathrm{pH}$ range 3.0-12.0. The residual activities (\%) which remained after incubating the enzyme in various buffers for $2 \mathrm{~h}$ at $30^{\circ} \mathrm{C}$ are also presented in Fig. 1.

The study conducted on the stability of the PG showed that the enzyme was stable in the $\mathrm{pH}$ range $3.0-7.0$ by retaining at least $65 \%$ of its activity. The stability of the enzyme was maximized at $\mathrm{pH} 3.0$ and decreased sharply above $\mathrm{pH}$ 8.0. Martin et al. ${ }^{10}$ reported two SSF PGs obtained from Moniliella sp. and Penicillium sp. preserving $70-100 \%$ of their initial activities between $\mathrm{pH} 3.0$ and 10.0 and $\mathrm{pH} 3.0$ and 8.0 respectively. Most of the PG enzymes stated in the literature lost more than $70 \%$ of their stability beyond $\mathrm{pH}$ 9.0. 7,9,12 The PG enzyme of the current study was superior to the crude PG enzyme produced by SmF from A. sojae ATCC 20235, which was reported to preserve its stability $(>65 \%)$ only at $\mathrm{pH} 5.0$ and $6.0 .{ }^{8}$ It is thought that the stability of the A. sojae mutant PG is compatible with fruit juice processing requirements. Additionally, the stability range of this PG should be considered in the packaging and storage stages of the possible end-product.

\section{Effect of temperature on activity and stability of PG}

The effect of temperature on the PG activity was determined by incubation of the reaction mixture $(\mathrm{pH} 4.8)$ for 20 min at different temperatures ranging from 25 to $80^{\circ} \mathrm{C}$. The results of the experiments are presented in Fig. 2.

Although the PG enzyme showed activity over a broad temperature range $\left(25-80^{\circ} \mathrm{C}\right)$, its optimum activity was at $40^{\circ} \mathrm{C}$. It retained $99 \%$ of its activity at $50^{\circ} \mathrm{C}$. Most researchers determined the optimum activity of their exo-PG enzymes (fungal or bacterial) between 40 and $60^{\circ} \mathrm{C} .6,7,11$ Ortega et al. ${ }^{31}$ found the optimum PG activities of three commercial pectinases Rapidase C80 (Gist-Brocades), Pectinase CCM (Biocon) and Pectinex 3XL (Novozyme) as 55,50 and $50^{\circ} \mathrm{C}$ respectively. This indicated that 


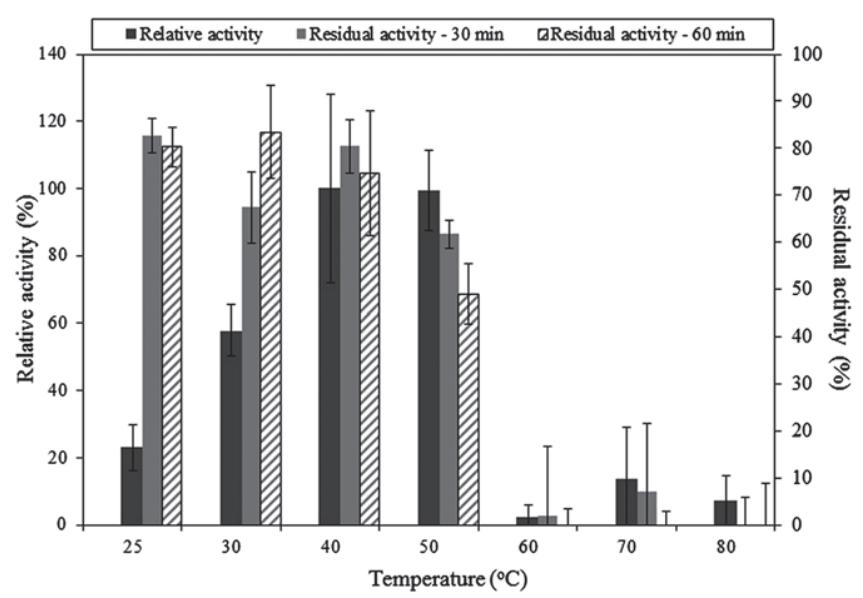

Figure 2. Effect of temperature on activity and stability of mutant Aspergillus sojae PG.

the PG of mutant $A$. sojae has compatible activity with these three commercial enzymes and its optimum temperature of $40-50{ }^{\circ} \mathrm{C}$ is very suitable for fruit juice clarification (enzymatic depectinization) applications, which are generally conducted between 30 and $50^{\circ} \mathrm{C}$. However, mutant $A$. sojae PG showed sensitivity at $60^{\circ} \mathrm{C}$ and could not be active at this temperature; therefore in the case of its use in the fruit juice clarification process the pasteurized juice should be cooled carefully to a temperature below $60^{\circ} \mathrm{C}$ before the addition of this enzyme.

In order to investigate the thermostability of the PG, the enzyme was incubated at various temperatures ranging between 25 and $80^{\circ} \mathrm{C}$ for 30 and $60 \mathrm{~min}$. The residual activities (\%) after these incubation periods are plotted in Fig. 2.

As can be seen in Fig.2, there was no significant difference between 30 and 60 min with respect to the thermostability of the enzyme. The mutant $A$. sojae PG could preserve more than $50 \%$ of its stability between 25 and $50{ }^{\circ} \mathrm{C}$, both for 30 and $60 \mathrm{~min}$. This property indicated that the PG has sufficient thermostability for the enzymatic depectinization of fruit juices held between 30 and $50^{\circ} \mathrm{C}$. Besides, the enzyme was found to have potential to be utilized in the cold depectinization process $\left(20^{\circ} \mathrm{C}\right)$ of fruit juices as well. However, the enzyme did not present any thermostability above $50^{\circ} \mathrm{C}$. The thermostability range of mutant $A$. sojae PG was narrower when compared with other studies. ${ }^{8-10}$

\section{Effect of metal ions and various compounds on PG stability}

The effect of 12 compounds and seven metal ions on the stability of the PG activity was investigated by incubating the PG enzyme in the presence of these reagents in the volumetric ratio of $1: 1$ at $30^{\circ} \mathrm{C}$ for $1 \mathrm{~h}$. The residual PG activity (\%) was determined with the standard PG activity assay and is tabulated in Table 2.

The PG enzyme activity was enhanced by 19 and $17 \%$ in the presence of acetic acid and citric acid respectively, which represent the total acidity of orange juice. ${ }^{20}$ Kapoor et al. ${ }^{11}$ reported a PG produced by SSF from Bacillus sp. MG-cp-2 that was also enhanced in the presence of $1 \mathrm{mmol} \mathrm{L}^{-1}$ citric acid. Moreover, the activity of the mutant $A$. sojae PG increased in the presence of sucrose and glucose and decreased slightly (17.67\%) in the presence of fructose, which were tested at their levels detected in orange juice by Kelebek et al. ${ }^{20}$ Another result was that the presence of organic and hydroxybenzoic acids, namely gallic, malic, tartaric and ascorbic acids (commonly found in orange and grape juices), significantly stimulated the activity of the PG, with rates of 35, 29.5, 22.5 and $32.8 \%$ respectively. These mentioned results are good indicators of the potential of the produced PG enzyme to be used in the fruit (especially orange and grape) juice and wine industry.

The PG enzyme was very stable in the presence of ammonium sulfate, which is allowed in grape cider (for the prevention of pulp oxidation) as stated in the wine communication under Turkish Food Codex Regulations (notification no. 2008/67). ${ }^{22}$ It also showed stability in the presence of $12.6 \%(\mathrm{v} / \mathrm{v})$ ethanol, which was measured by Kelebek et al. ${ }^{20}$ in orange wine. During the wine production process, pectic enzymes can be added while the grapes are being crushed, before or after fermentation of the must or after fermentation when the wine is ready for bottling. It was also reported that the addition of pectic enzymes at the last stage (after fermentation) increases the filtration rate and clarity. However, it was pointed out that the supplemented enzyme level should be adjusted in order to avoid the inhibitory effect of the alcohol on the enzyme. ${ }^{3}$ As can be seen in Table 2, mutant $A$. sojae PG was not inhibited in the presence of $12.6 \%(\mathrm{v} / \mathrm{v})$ ethanol; in fact, it was stimulated by $13 \%$. Rodriguez et al. ${ }^{32}$ similarly observed that an ethanol concentration up to $15 \%$ (v/v) enhanced the enzyme activities of $\beta$-xylosidases from Candida guilliermondii. Since both enzymes and substrates may contain charged groups, this stimulation may be due to the change in the dielectric constant of the medium as well as its ionic strength and polarity with the addition of ethanol, which may have resulted in the increased enzymatic reaction rates and/or substrate solubility. ${ }^{33,34}$ This property of the currently produced PG enzyme indicates its potential application in the clarification of wines.

There are a few reports on the effect of metal ions and compounds on the pectinases produced from solid-state fermentation. Therefore the PG of this study was also compared with the pectinases produced by SmF in addition to the SSF pectinases reported in the literature. With this perspective, the PG of mutant $A$. sojae produced by SSF as described in the current study was quite stable in the presence of the most of the cations tested, unlike the other pectinase extracts produced by either SSF or SmF reported in the literature.

The PG enzyme activity was stimulated by $\mathrm{Mn}^{2+}, \mathrm{Cu}^{2+}, \mathrm{Mg}^{2+}$ and $\mathrm{Na}^{+}$, which indicated the possibility of them acting as salt or ion bridges that stabilize the enzyme in its active conformation and might protect the enzyme against thermal denaturation, or this is a metalloprotein needing a cofactor for higher activities. ${ }^{35,36}$ On the contrary, many PGs were reported to be inhibited by these cations. For example, PG (by SmF) of Mucor circinelloides ${ }^{37}$ was inhibited in the presence of $1 \mathrm{mmol} \mathrm{L}^{-1} \mathrm{Mg}^{2+}, \mathrm{Mn}^{2+}$ and $\mathrm{Cu}^{2+}$, extracellular PG (by SmF) of T. aurantiacus ${ }^{38}$ was inhibited by $2 \mathrm{mmol} \mathrm{L}^{-1} \mathrm{Mn}^{2+}$ and $\mathrm{Mg}^{2+}$, while PG (by SmF) of Trichoderma harzianum was inhibited by $1 \mathrm{mmol} \mathrm{L}^{-1} \mathrm{Mg}^{2+}, \mathrm{Mn}^{2+}$ and $\mathrm{Cu}^{2+} .39$ The effect of metal ions could be important in the use of raw materials with a high salt content. $^{24}$

On the other hand, mutant $A$. sojae PG was stable in the presence of $0.5 \mathrm{mmol} \mathrm{L}^{-1}$ ethylenediaminetetraacetic acid (EDTA). This result revealed that the PG of mutant $A$. sojae did not depend on the presence of metals, otherwise it could not show activity in the presence of a metal chelator, i.e. EDTA.

Among the investigated metal ions, only the presence of $\mathrm{CaCl}_{2}$ and $\mathrm{FeCl}_{3}$ inhibited the PG activity, by 7 and $24 \%$ respectively. This result is compatible with PG of Sporotrichum thermophile Apinis ${ }^{40}$ for $5 \mathrm{mmol} \mathrm{L}^{-1} \mathrm{Ca}^{2+}$ and extracellular pectinase (by SSF) of Acrophialophora nainiana ${ }^{41}$ for $12.5 \mathrm{mmol} \mathrm{L}^{-1} \mathrm{Ca}^{2+}$, whereas the PG (by SSF) of Bacillus sp. MG-cp- $2^{11}$ was stimulated with 


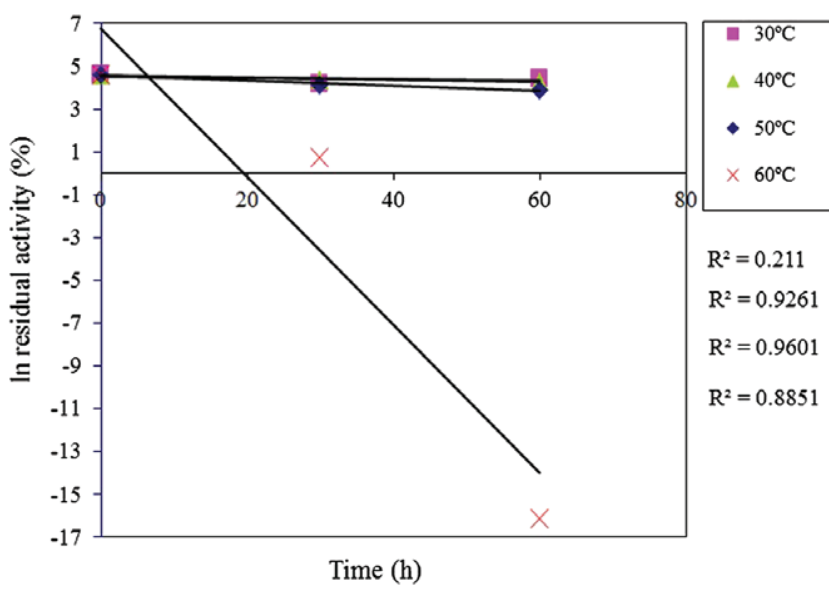

Figure 3. First-order plots of effect of thermal denaturation of mutant Aspergillus sojae PG and closer view for trend lines of 30,40 and $50^{\circ} \mathrm{C}$.

$1 \mathrm{mmol} \mathrm{L}^{-1} \mathrm{Ca}^{2+}$. The exo-PGs (by SmF) of Streptomyces sp. QK-11-3 and Bacillus sp. strain KSM-P443 were similarly reported to be inhibited by $\mathrm{Fe}^{3+}$ by Beg et $a .^{42}$ and Kobayashi et al. ${ }^{5}$ respectively.

When we compared the PG of mutant $A$. sojae PG (SSF) with the PG of A. sojae ATCC 20235 (wild type) produced by the SmF technique by Dogan and Tari, ${ }^{43}$ some differences in the behavior of these two PGs were observed. For example, wild-type A. sojae PG was completely inhibited by $1 \mathrm{mmol} \mathrm{L}^{-1} \mathrm{Mn}^{2+}$ after an incubation period of $30 \mathrm{~min}$, contrary to the mutant $A$. sojae PG. Additionally, wild-type $A$. sojae PG was similarly stimulated by $1 \mathrm{mmol} \mathrm{L}^{-1} \mathrm{KCl}$ and $\mathrm{NaCl}$ but was inhibited by $\mathrm{Mg}^{2+}$ and $\mathrm{Cu}^{2+}$, unlike the mutant A. sojae PG. ${ }^{43}$ These results indicated that microbial source and fermentation type are among the factors significantly affecting the biochemical properties of exo-PGs.

\section{Kinetics of thermal inactivation and estimation of inactivation energy}

In general, temperature is the most important variable in all biological systems and in enzymatic processes as well. Enzymes are referred to be complex labile proteins and biocatalysis occurs under non-natural conditions, where the native properties of the enzymes can be significantly altered. Therefore it is not surprising that the temperature has a profound impact not only on enzyme activity but also on enzyme stability. As a general rule, as the temperature increases, the reaction rate of the catalyzed chemical reaction and the rate of enzyme inactivation increase. The thermal inactivation of the enzyme is a result of weakening of the intermolecular forces that are responsible for the 3D structure of the enzyme. The thermal inactivation causes a reduction in catalytic capacity of the enzyme. Therefore knowledge on the thermal inactivation of the enzyme is critical to properly evaluate the performance of the enzyme under process conditions. ${ }^{33}$

The inactivation of pectolytic enzymes is assumed to follow first-order kinetics. ${ }^{44}$ The first-order deactivation rate constants were calculated from the slope of semi-logarithmic plots of residual activity vs time (Fig. 3 ) and are presented in Table 3 for the temperatures of $30,40,50$ and $60^{\circ} \mathrm{C}$. The $k_{d}$ (deactivation rate constant) values indicated that the enzyme was most stable at $30^{\circ} \mathrm{C}$, but a rapid loss of activity was obtained at $60^{\circ} \mathrm{C}$. Similarly, the calculated $k_{\mathrm{d}}$ values for the exo-PG produced from $A$. niger by SSF increased significantly above $50{ }^{\circ} \mathrm{C} .{ }^{45}$

Half-life values of the enzyme were estimated from the calculated $k_{\mathrm{d}}$ values using Eqn (1) and are tabulated in Table 3.
Table 3. Kinetic parameters for thermal inactivation of mutant Aspergillus sojae PG

\begin{tabular}{|c|c|c|}
\hline$T(\mathrm{~K})$ & $k_{\mathrm{d}}\left(\min ^{-1}\right)$ & $t_{1 / 2}(\min )$ \\
\hline 303 & 0.0030 & 231.049 \\
\hline 313 & 0.0049 & 141.459 \\
\hline 323 & 0.0119 & 58.248 \\
\hline 333 & 0.3454 & 2.007 \\
\hline$E_{\mathrm{d}}\left(\mathrm{kJ} \mathrm{\textrm {mol } ^ { - 1 } )}\right.$ & \multicolumn{2}{|c|}{125.3} \\
\hline
\end{tabular}

Table 4. Thermodynamic parameters for thermal inactivation of mutant Aspergillus sojae PG

\begin{tabular}{|cccc|}
$T(\mathrm{~K})$ & $\left.\Delta H^{*}(\mathrm{~kJ} \mathrm{~mol})^{-1}\right)$ & $\Delta G^{*}\left(\mathrm{~kJ} \mathrm{~mol}^{-1}\right)$ & $\Delta S^{*}\left(\mathrm{~kJ} \mathrm{~mol}{ }^{-1} \mathrm{~K}\right)$ \\
\hline 303 & 122.78 & 88.89 & 0.11 \\
313 & 122.70 & 90.63 & 0.10 \\
323 & 122.61 & 91.23 & 0.10 \\
333 & 122.53 & 84.81 & 0.11 \\
\hline
\end{tabular}

The half-life dramatically reduced from $231.05 \mathrm{~min}$ at $30^{\circ} \mathrm{C}$ to $2.007 \mathrm{~min}$ at $60^{\circ} \mathrm{C}$. A similar trend was reported by Ortega et al. ${ }^{31}$ for commercial pectinases: half-life values (in phase II) were 209.74 and $409.79 \mathrm{~min}$ for Rapidase $\mathrm{C} 80$ and Pectinase CCM at $40^{\circ} \mathrm{C}$, which reduced to 7.80 and $61.78 \mathrm{~min}$ at $60^{\circ} \mathrm{C}$, respectively. ${ }^{31}$

The inactivation energy $\left(E_{\mathrm{d}}\right)$ of mutant $A$. sojae PG was determined as $125.3 \mathrm{~kJ} \mathrm{~mol}^{-1}$ from the slope of the linear curve plotted by $1 / T v s \ln k_{d}$ using Eqn (3) (not shown). This value is in accordance with the $E_{\mathrm{d}}$ obtained as $128.91 \mathrm{~kJ} \mathrm{~mol}^{-1}$ for the exo-PG of $A$. niger by Diaz et al. ${ }^{45}$ and is 1.64 times higher than that of Pectinase CCM but 1.16 and 1.27 times lower than those of Rapidase C80 and Pectinex $3 X L$ respectively. ${ }^{31}$ The partially purified PG of $A$. sojae ATCC 20235 (wild type) was reported to have a superior $E_{\mathrm{d}}$ of $286.2 \mathrm{~kJ} \mathrm{~mol}^{-1}, 43$ but an approximate $E_{\mathrm{d}}$ of $152 \mathrm{~kJ} \mathrm{~mol}^{-1}$ was obtained with the crude PG of the same strain. ${ }^{8}$ These results revealed that the current PG has potential use in applications below $60^{\circ} \mathrm{C}$; however, a further purification may enhance some of its biochemical properties.

\section{Estimation of thermodynamic parameters during inactivation of PG}

The changes in the enthalpy $\left(\Delta H^{*}\right)$ and entropy $\left(\Delta S^{*}\right)$ for the thermal inactivation of the PG were calculated according to Eqns (4) and (6) by transition state theory. ${ }^{44}$ Positive $\Delta H^{*}$ values were obtained with the investigated temperatures (Table 4), indicating the endothermic nature of the inactivation reaction. The free energy of inactivation $\left(\Delta G^{*}\right)$ decreases slightly as the temperature increases. This means that less energy is needed for inactivation of the enzyme at $60^{\circ} \mathrm{C}$, which is in accordance with the thermal stability results given above.

Naidu and Panda ${ }^{44}$ predicted that entropy values provide information regarding the degree of solvation and very likely the degree of compactness of protein molecules. An increase in entropy indicates opening up of the enzyme structure. ${ }^{24}$ As can be seen in Table 4, $\Delta S^{*}$ did not change significantly with increasing temperature, which means that thermal deactivation did not imply any relevant variation in the enzyme tertiary structure. Moreover, Ortega et al. ${ }^{31}$ stated that a large activation enthalpy is characteristic of the protein denaturation reaction. However, $\Delta H^{*}$ values did not vary with increasing temperature, supporting the idea 


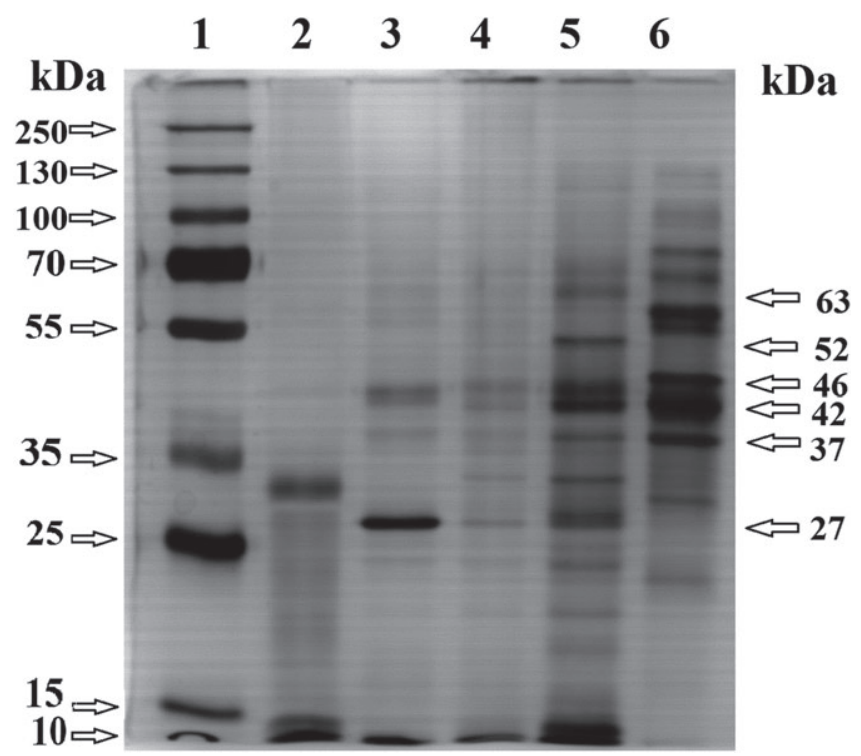

Figure 4. SDS-PAGE profiles: lane 1, molecular weight marker; lane 2, PG from SmF; lane 3, PG from flask; lane 4, PG from bioreactor; lane 5, PG from glass tray; lane 6, commercial pectinase.

that enzyme unfolding may not be the rate-determining step for the irreversible thermal inactivation of PG under the conditions assayed.

\section{SDS-PAGE analysis of PG enzymes}

A protein profile investigation of the crude PG enzymes from submerged (SmF), flask, bioreactor and tray scales (SSF) was performed by comparing the protein bands with the molecular weight marker within the range $10-250 \mathrm{kDa}$. It should be noted that the produced enzymes run on lanes $2-5$ were crude, therefore a single protein band was not expected. The aim was to present the protein band profile of the crude enzymes produced by a mutant A. sojae using various fermentation conditions and the molecular weight ranges to which they belong.

When the protein bands of SmF (lane 2) are compared with those of SSF (lanes 3-5) in Fig. 4, different kinds of protein bands can be seen for the crude enzymes produced by the SSF technique. One reason may be the type of fermentation, where the fungus is in tight contact with the substrate in SSF but is only exposed to the water-soluble part of the substrate in SmF, which results in the synthesis of different proteins. Other reason may be the difference between the fermentation media formulations. The SSF proteins were determined within the range $18-64 \mathrm{kDa}$, which is in accordance with the molecular weight range of the reported exo-PGs (30-70 kDa) listed in Table 1.

As can be seen in Fig. 4, the protein band profiles of the three SSF enzymes were similar to each other. The protein band at $27 \mathrm{kDa}$ was obtained in all SSF enzymes (lanes 3-5), but it was more distinct for the flask-scale enzyme (lane 3). Another identical band was obtained at ca $37 \mathrm{kDa}$ for the SSF enzymes (lanes 3-5), which was also obtained with the commercial pectinase (lane 6). A further feature of Fig. 4 is the broad protein band profile of the tray enzyme (lane 5) compared with the flask-scale SSF enzyme (lane 3). This may indicate an attempt by the fungus to adapt to a different medium (tray) by synthesizing different kinds of hydrolytic enzymes. The last common protein bands were obtained at ca 41 and 44 kDa for the SSF enzymes (lanes 3-5).

\section{CONCLUSIONS}

The results of this study showed that the produced PG with relatively high enzymatic activity has satisfactory biochemical properties compatible with commercial pectinases. It was also concluded that the mutant $A$. sojae PG could be suitable for the clarification (depectinization) of fruit juices and wine, especially orange and grape juices. Therefore it is thought to be worthwhile to study the purification of this enzyme in order to further improve its biochemical properties. The biochemical characterization also clearly showed that this high-activity PG produced using a residue of the food industry has the potential to be recycled to the food industry as a value-added product.

\section{ACKNOWLEDGEMENTS}

Professor Dr Marcello Fernandez Lahore and his research group from Jacobs University, Bremen, Germany are kindly acknowledged for the supply of the mutant strain. The Biotechnology and Bioengineering Research and Application Centre of Izmir Institute of Technology is gratefully acknowledged by the authors.

\section{REFERENCES}

1 Niture SK, Comparative biochemical and structural characterizations of fungal polygalacturonases. Biologia 63:1-19 (2008).

2 Jayani RS, Saxena S and Gupta R, Microbial pectinolytic enzymes: a review. Process Biochem 40:2931 - 2944 (2005).

3 Kashyap DR, Vohra PK, Chopra S and Tewari S, Applications of pectinases in the commercial sector: a review. Bioresour Technol 77:215-227 (2001).

4 Gummadi SN, Manoj N and Kumar DS, Structural and biochemical properties of pectinases, in Industrial Enzymes, ed. by Polaina J and MacCabe AP. Springer, Heidelberg, pp. 99-115 (2007).

5 Kobayashi T, Higaki N, Yajima N, Suzumatsu A, Hagihara H, Kawal S, et al., Purification and properties of a galacturonic acid-releasing exopolygalacturonase from a strain of Bacillus. Biosci Biotechnol Biochem 65:842-847 (2001).

6 Dinu D, Nechifor MT, Stoian G, Costache M and Dinischiotu A, Enzymes with new biochemical properties in the pectinolytic complex produced by Aspergillus niger MIUG 16. J Biotechnol 131:128-137 (2007).

7 Freitas P, Martin N, Silva D, Silva R and Gomes E, Production and partial characterization of polygalacturonases produced by thermophilic Monascus sp. N8 and by thermotolerant Aspergillus sp. N12 on solid-state fermentation. Braz J Microbiol 37:302-306 (2006).

8 Tari C, Dogan N and Gogus N, Biochemical and thermal characterization of crude exo-polygalacturonase produced by Aspergillus sojae. Food Chem 111:824-829 (2008).

9 Martins ES, Silva D, Silva R and Gomes E, Solid state production of thermostable pectinases from thermophilic Thermoascus aurantiacus. Process Biochem 37:949-954 (2002).

10 Martin N, Souza RS, Silva R and Gomes E, Pectinase production by fungal strains in solid-state fermentation using agro-industrial bioproduct. Braz Arch Biol Technol 47:813-819 (2004).

11 Kapoor M, Beg QK, Bhushan B, Dadhich KS and Hoondal GS, Production and partial purification and characterization of a thermo-alkali stable polygalacturonase from Bacillus sp. MG-cp-2. Process Biochem 36:467-473 (2000).

12 Acuna-Arguelles ME, Gutierrez-Rojas M, Viniegra-Gonzales $G$ and Favela-Torres $\mathrm{E}$, Production and properties of three pectinolytic activities produced by Aspergillus niger in submerged and solid-state fermentation. Appl Microbiol Biotechnol 43:808-814 (1995).

13 Galiotou-Panayotou M, Kapantai M and Kalantzi O, Growth conditions of Aspergillus sp. ATHUM-3482 for polygalacturonase production. Appl Microbiol Biotechnol 47:425-429 (1997).

14 Pedrolli DB and Carmona EC, Purification and characterization of the exopolygalacturonase produced by Aspergillus giganteus in submerged cultures. J Ind Microbiol Biotechnol 37:567-573 (2010).

15 Demir $\mathrm{H}$ and Tari C, Valorization of wheat bran for the production of polygalacturonase in SSF of Aspergillus sojae. Ind Crops Prod 54:302-309 (2014). 
16 Nicolás-Santiago DS, Regalado-González C, García-Almendárez B, Fernández FJ, Téllez-Jurado A and Huerta-Ochoa S, Physiological, morphological, and mannanase production studies on Aspergillus niger UAM-GS1 mutants. Electron J Biotechnol 9:51-60 (2006).

17 Göğüş N, Tari C, Oncü S, Unluturk S and Tokatli F, Relationship between morphology, rheology and pectinase production by Aspergillus sojae ATCC 20225 in submerged cultures. Biochem Eng J 32:171-178 (2006).

18 Demir H, Göğüş N, Tari C, Heerd D and Lahore MF, Optimization of the process parameters for the utilization of orange peel to produce polygalacturonase by solid-state fermentation from an Aspergillus sojae mutant strain. Turk J Biol 36:394-404 (2012).

19 Panda T, Naidu G and Sinha J, Multiresponse analysis of microbiological parameters affecting the production of pectolytic enzymes by Aspergillus niger: a statistical view. Process Biochem 35:187-195 (1999).

20 Kelebek H, Selli S, Canbas A and Cabaroglu T, HPLC determination of organic acids, sugars, phenolic compositions and antioxidant capacity of orange juice and orange wine made from a Turkish cv. Kozan. Microchem J 91:187-192 (2009).

21 Ehling $S$ and Cole S, Analysis of organic acids in fruit juices by liquid chromatography-mass spectrometry: an enhanced tool for authenticity testing. J Agric Food Chem 59:2229-2234 (2011).

22 Turkish Food Codex Regulations, Wine communication (notification no. 2008/67) (in Turkish). Official Gazette 04.02.2009-27131 [Online]. Available: http://www.resmigazete.gov.tr [2 September 2015].

23 Shuler ML and Kargi F, Bioprocess Engineering Basic Concepts (2nd edn). Prentice Hall, Upper Saddle River, NJ, pp. 57-104 (2002).

24 Bhatti HN, Asgher M, Abbas A, Nawaz R and Sheikh MA, Studies on kinetics and thermostability of a novel acid invertase from Fusarium solani. J Agric Food Chem 54:4617-4623 (2006).

25 Laemmli UK, Cleavage of structural proteins during the assembly of the head of bacteriophage T4. Nature 227:680-685 (1970).

26 Bradford MM, A rapid and sensitive method for the quantitation of microgram quantities of protein utilizing the principle of protein-dye binding. Anal Biochem 72:248-254 (1976).

27 Göğüss N, Hakgüder Taze B, Demir H, Tari C, Ünlütürk S and Lahore MF, Evaluation of orange peel, an industrial waste, for the production of Aspergillus sojae polygalacturonase considering both morphology and rheology effects. Turk J Biol 38:537-548 (2014).

28 Demir H, Çoban I, Sargin S and Tari C, Scale-up of polygalacturonase production in a horizontal drum solid-state bioreactor. 2013 IFT Annual Meeting, Chicago, IL, pp. 256-257 (2013).

29 Demir $\mathrm{H}$ and Tari $\mathrm{C}$, Bioconversion of wheat bran for polygalacturonase production by Aspergillus sojae in tray type solid-state fermentation. Int Biodeterior Biodegrad 106:60-66 (2016).

30 Chevallet $\mathrm{M}$, Luche $\mathrm{S}$ and Rabilloud T, Silver staining of proteins in polyacrylamide gels. Nat Protocols 1:1852-1858 (2006).
31 Ortega N, de Diego S, Perez-Mateos M and Busto MD, Kinetic properties and thermal behaviour of polygalacturonase used in fruit juice clarification. Food Chem 88:209-217 (2004).

32 Rodriguez ME, Lopes C, Valles S, Giraudo MR and Caballero A, Selection and preliminary characterization of $\beta$-glycosidases producer Patagonian wild yeasts. Enzyme Microb Technol 41:812-820 (2007).

33 Illanes A, Altamirano C and Lorena W, Homogeneous enzyme kinetics, in Enzyme Biocatalysis Principles and Applications, ed. by Illanes A. Springer, Dordrecht, pp. 107-154 (2008).

34 Bonner PLR, Protein Purification. Taylor and Francis, London, pp. 25-78 (2007).

35 Corrêa APF, Daroit DJ and Brandelli A, Characterization of a keratinase produced by Bacillus sp. P7 isolated from an Amazonian environment. Int Biodeterior Biodegrad 64:1 - 6 (2010).

36 Balkan B and Ertan $\mathrm{F}$, The production of a new fungal $\alpha$-amylase degraded the raw starch by means of solid-state fermentation. Prep Biochem Biotechnol 40:213-228 (2010).

37 Thakur A, Pahwa R, Singh S and Gupta R, Production, purification, and characterization of polygalacturonase from Mucor circinelloides ITCC 6025. Enzyme Res 2010:170549 (2010).

38 Martins ES, Silva D, Leite RSR and Gomes E, Purification and characterization of polygalacturonase produced by thermophilic Thermoascus aurantiacus CBMAI-756 in submerged fermentation. Antonie Leeuwenhoek 91:291-299 (2007)

39 Mohamed SA, Farid NM, Hossiny EN and Bassuiny Rl, Biochemical characterization of an extracellular polygalacturonase from Trichoderma harzianum. J Biotechnol 127:54-64 (2006).

40 Kaur G, Kumar S and Satyanarayana T, Production, characterization and application of a thermostable polygalacturonase of a thermophilic mould Sporotrichum thermophile Apinis. Bioresour Technol 94:239-243 (2004).

41 Celestino SMC, de Freitas SM, Medranoc FJ, de Sousa MV and Filho EXF, Purification and characterization of a novel pectinase from Acrophialophora nainiana with emphasis on its physicochemical properties. J Biotechnol 123:33-42 (2006).

42 Beg QK, Brushan B, Kapoor M and Hoondal GS, Production and characterization of thermostable xylanase and pectinase from Streptomyces sp. QG-11-3. J Ind Microbiol Biotechnol 24:396-402 (2000).

43 Dogan N and Tari C, Characterization of three-phase partitioned exo-polygalacturonase from Aspergillus sojae with unique properties. Biochem Eng J 39:43-50 (2008).

44 Naidu GSN and Panda T, Studies on pH and thermal deactivation of pectolytic enzymes from Aspergillus niger. Biochem Eng J 16:57-67 (2003).

45 Diaz AB, de Ory I, Caro I and Blandino A, Enhanced hydrolytic enzymes production by Aspergillus awamori on supplemented grape pomace. Food Bioprod Process 90:72-78 (2012). 